is to encourage fundamental research work along lines which will assist the work of the Authority in this field. Research on the control of the thermonuclear reaction has been going on at Harwell for some time. The conference will be held in private, and no statement will be issued afterwards.

\section{Central Pool of Officers for the Oversea Civil Service}

ON May 17 the Secretary of State for the Colonies, Mr. A. Lennox-Boyd, made a statement regarding the Oversea Civil Service, further details of which were given in a White Paper published the same day. Mr. Lennox-Boyd said that the Government has decided in principle to establish a central pool of officers with exceptional administrative or professional qualifications who would be employed by the Government in the United Kingdom and be made available as required for secondment to overseas Governments. The central pool will be set up as soon as possible. Meanwhile, to meet an urgent staffing position which has arisen in the territories comprising the Federation of Nigeria, it is proposed, subject to the agreement of the Nigerian Government, to introduce a scheme by which existing expatriate pensionable officers can transfer, on certain conditions, to a special list of the Oversea Civil Service, and officers so admitted will thenceforth be in the service of the Government and seconded to the local Governments. The scheme will be in a form that will permit similar arrangements to be applied to other territories if considered desirable. In reply to questions, Mr. Lennox-Boyd added that officers transferred to the special list will be paid by the employing countries, at rates prescribed by the British Government after consultation with those countries, and that H.M. Government will pay the pensions and recover the money from the Government in whose service the pensions were earned.

\section{Fluoridation of Potable Water in Britain}

IN view of repeated allegations that the addition of fluoride to public water supplies might have harmful effects, the Minister of Health has again consulted the Medical Research Council. The Council has transmitted to the Minister the advice of a conference of experts, which it called to review the subject, that there is no evidence warranting alteration or abandonment of the fluoridation projects. The experts agreed in general with the conclusions of the United Kingdom Mission (1953) to the effect that, despite considerable interest and research, there is no definite evidence that the continued consumption of fluorides in water at a level of about 1 p.p.m. in drinking water is in any way harmful to health, and they consider that if any untoward effect is revealed by future research this is most unlikely to be serious.

\section{Industrial Welfare Society}

IN the annual report for 1955, the director of the Industrial Welfare Society, Mr. John Marsh, suggests that side by side with the demands for scientific and technical achiovement in industry, thero is a great need for men who have personal qualities and who can influence workers at all levels to be self-respecting, co-operative and efficient. Personal qualities are not only needed among those concerned with management but also among the specialists. The technical specialists of industry can create human problems which sometimes offset the efficiency they set out to achieve. For example, the noed for work-study engineers is undoubtedly great; but industry must select men for training in these tasks who are fundamentally sound in their knowledge and understanding of their fellow men. They must certainly know something about the effect of changes in skill on a man's reason and emotions. Among other items referred to by Mr. Marsh are the lack of clearly defined promotion systems in the majority of industrial concerns and the amazing dearth of suitable reading matter for the largo number of supervisors and apprentices in industry.

\section{A Bibliography of Plant Protection}

UNDER this title a comprehensive work covering the year 1951 has been issued in German, English and French by the Biologische Bundersanstalt für Land- und Forstwirtsehaft in Berlin-Dahlem, under the editorship of Dr. J. Bärner (pp. xliv +\$20 ; Paul Parey, Berlin and Hamburg, 1955). This bibliography, which comprises more than 12,500 titles, is in continuity with the original publication on this subject begun in 1921 and already including twentytwo volumes covering the years 191s-4.5. The volumes covering the years 1946-50 are to follow in the near future. The original layout has been maintained and includes a general section dealing with collective works, text-books, reports of congresses, bibliographies, etc., followed by other sections on diseases and their causes, diseases and host plants, measures of plant protection and an index of authors.

\section{University of Leeds: Appointments}

Dr. C. E. Lumsden, of the Institute of Neurology, London, has been appointed professor of pathology and head of the Department of Pathology in the University of Leeds. The following have been appointed lecturers in the University: Dr. R. O. Gandy (applied mathematics), R. J. R. Hayward (Brotherton lecturer in inorganic and structural chemistry), Dr. G. R. Higginson (mechanical engineering), M. A. Jeeves (psychology), Dr. L. Mackinnon (physics), P. Sutcliffe (civil engineering) and W. H. Trickett (statistics).

\section{University of London: Appointments}

Mr. J. D. Evans, Research Fellow at Pembroke College, Cambridge, has been appointed to the University of London chair of prehistoric European archæology, tenable at the Institute of Archæology, and Dr. J. H. Birkinshaw, reader in biochemistry at the London School of Hygiene and Tropical Medicine, has been appointed to the University of London chair of biochemistry, tenable at that School. The following have been appointed to University readerships tenable at the Colleges indicated: P. T. Fink (Imperial College of Science and Technology), aeronautics; Dr. G. P. Wibberley (Wye College), agriculture with special reference to agricultural economics; and Dr. W. L. Wilcock (Imperial College of Science and Technology), instrument technology.

\section{University of Sheffield}

IN the University of Sheffield the Refractories Section of the Department of Metallurgy has been created a separate Department of Refractories 'Technology with Prof. J. White as its head. The title of reader in electrical machinery in the University has been conferred on O. I. Butler, senior lecturer in electrical engineering. Dr. G. B. Greenough, senior lecturer in physical metallurgy, has resigned from the University on appointment as research 